Article

\title{
The Impact of South Korea Golf Resort Social Network Services Advertising and Online Word of Mouth on Consumer Brand Value
}

\author{
Taesoo Cho ${ }^{1,+}$, Taeyoung Cho ${ }^{2,+}$, Guosong Zhao ${ }^{3}$ and Hao Zhang ${ }^{4, * \mathbb{C}}$ \\ 1 School of Exercise and Sport Science, University of Ulsan, Ulsan 44610, Korea; cts1119@hanmail.net \\ 2 Department of Hotel Tourism Management, Dongguk University, Gyeongju 38066, Korea; \\ cty0629@dongguk.ac.kr \\ 3 School of Geography and Information Engineering, China University of Geosciences, Wuhan 430078, China; \\ zhaoguosong@cug.edu.cn \\ 4 Key Laboratory of Land Surface Pattern and Simulation, Institute of Geographic Sciences and Natural \\ Resources Research, Chinese Academy of Sciences, Beijing 100101, China \\ * Correspondence: zhanghao@igsnrr.ac.cn \\ + The first two authors contributed equally to this work.
}

Received: 26 April 2020; Accepted: 23 May 2020; Published: 26 May 2020

check for updates

\begin{abstract}
Today, social network services (SNS) advertising is frequently utilized by enterprises to communicate with consumers as it provides the best marketing effect using low-cost media. Since the value of SNS is increasing, managers need to look for more effective methods of utilizing the existing SNS channels. This study aims to provide suggestions for attracting customers and gaining an advantage amid the stiff competition among similar golf courses. To achieve the goal of this study, a questionnaire-based survey was conducted at six golf resorts in South Korea where SNS advertising has been used to enhance consumer experiences. The study found that SNS advertising and online word of mouth regarding golf resorts have a positive effect on emotive, social, and price values. Moreover, SNS advertising for golf resorts had a positive effect on the quality function value, while online word of mouth had no effect.
\end{abstract}

Keywords: golf resort; SNS advertising; online word of mouth; brand price

\section{Introduction}

With the development of wireless networks and the proliferation of mobile devices [1], we are now living in a communication environment with enhanced personalization and mobility. In addition, social network services (SNS) have diffused rapidly around the world, and enterprises are increasingly using SNS to attract customers and communicate with them [2]. Research also shows that SNS have a positive impact on the profits and operation of enterprises, and the diversity of SNS utilization plans is increasing [3,4].

In a golf resort, SNS adverting provides services to consumers, which leads to repeat visits. The characteristics of SNS are different from that of the existing mass media due to its interactivity and its ability to produce and share various information through a network based on individual information [5]. Particularly, as a result of SNS experience, online word of mouth is essential in gathering information and it can be a successful management strategy for the managing company. ComScore once predicted that the use of SNS as a means of service marketing will increase by more than $21 \%$, and that it will increase in the US [6]. As SNS advertising has a relatively low cost, it can reach a variety of users, and will see increased use in the future. 
With the development of SNS, online word of mouth has subsequently naturally developed [7]. There are three types of online word of mouth in SNS: seeking opinions, providing opinions, and transmitting opinions. Seeking opinions refers to consumers' tendency to seek information and advice from others when making decisions, such as buying products; providing opinions is an individual's intention to share their opinion with others; and transmitting opinions is defined as the willingness to share an opinion or information about a particular product to others for noncommercial purposes [8,9]. The rapid development of the internet today has led online word of mouth to be the emerging marketing communication strategy for new products, and it is gradually receiving increased attention from businesses [10]. Based on the preceding theory, we found that both SNS advertising and word of mouth are important factors [11]. The analysis result of the preceding study has also shown that SNS advertising and word of mouth used in golf resorts, whether positive or negative, will play an important role in golf resort management $[12,13]$. As this study progresses, SNS advertising and online word of mouth, which are the differentiated marketing activities of golf resorts, can be used to attract customers and can be valuable for corporate management using SNS. Therefore, this study can be used to suggest brand value formation and golf resort marketing methods that characterize the brand of golf resorts.

The study's theoretical and practical implications are as follows. First, the theoretical implication is that, in the previous studies, the study that verified the relationship between SNS advertising, word of mouth, and brand value for golf resorts was insufficient, and a usable framework for follow-up studies was prepared. Secondly, as a practical implication, increasing the brand value is necessary, and actively done using SNS advertisements and online word of mouth for consumers according to technological changes. Rather than simple unilateral advertising through the media, SNS advertisements with channels to communicate with consumers should improve corporate performance.

To achieve these research objectives, this study first established research hypotheses and proposed research models based on prior studies on SNS advertisements, word of mouth, and brand value. Secondly, we introduced the research design, which comprises the data collection and statistical analysis methods. Thirdly, multiple analyses (exploratory factor, reliability, correlation, and multiple regression) are conducted. Finally, we conclude with a summary comparing previous studies and present practical recommendations.

\section{Theoretical Background}

\subsection{SNS Advertising}

SNS advertising is defined as an advertisement message that can be controlled by advertisers to expose and disclose information to consumers based on the characteristics of the interactive content between the company and consumer [3]. As defined by Boyd and Ellison [3], based on the advertising attributes of Ducoffe [14] and Henning-Thurau et al. [15], SNS advertising refers to a kind of activity in which individuals or companies inform and promote a product or service to SNS users. Van Doorn et al. [16] and Safko and Brake [17] started migrating from an offline to online network space and implemented SNS, enabling the consumers to share their opinions and receive information. Moreover, companies insist that images, videos, text, and so on should be used as part of the marketing method through online SNS. Armano emphasized that the channel of marketing communication has changed from the era of traditional marketing communication based on traditional media, such as broadcasting and printing, through the era of internet banners, micro sites, email, and search advertisement, to a new paradigm of participation and sharing [18]. SNS is at the center of this change [19]. According to Hassan, et al. [20] and Park et al. [21], consumers deem SNS advertising to be entertaining, credible, and unobtrusive in terms of information transmission. In addition, consumers enjoy content about products, promotions, and prices that are personalized in an SNS advertisement. Chang et al. [22] and Taylor et al. [23] also highlighted the importance of SNS advertising in their study. Recently, airlines have begun providing special information through SNS to guide consumers to their 
websites for purchase, offering discounts on transportation or hotels at the consumers' destinations to induce consumers to consider their airline choices when choosing airlines. Mun and Cho [24] also stated that the SNS advertising of a golf course is essential for customer satisfaction and reuse, and while SNS information enhances golf resort management, it requires continuous management. Therefore, SNS advertising becomes an important service that must be managed by sports companies.

\subsection{Online Word of Mouth}

Online word of mouth occurs in a network or mobile phone SNS [15], and it is defined as sending positive or negative messages about a related company, product, or service that the user has experienced to other consumers on advertisement boards or through chat services. For golf resorts, online word-of-mouth messages play a role in driving the process that satisfies all social, economic, and brand values [25]. Moreover, word of mouth is very vital as, on one the hand, it can pose a risk to corporate management when it is negative, and, on the other hand, it can form strong relationships with consumers when it is positive $[26,27]$. In particular, word of mouth that contains recommendations to others is considered to be the source of information that has the most effect before buying [28-30]. Anastasiei and Dospinescu also emphasized that positive word of mouth can be created if a product or service meets or exceeds the expectations of customers [31]. Apparently, word of mouth can influence customers' pre-purchase decision-making, so companies are attempting to share positive memories through word of mouth and to encourage the use of web-based SNS [31].

Web-based SNS provide a creative way to learn about a product or service directly from other consumers. Deloitte's Travel Survey [32] found that $83 \%$ of respondents said they used the Internet for research before buying travel products in the past 12 months, as it was easy and convenient. Further, for travel planning, according to the report by Krame et al. [33], 77\% of respondents received information from reviews that other consumers wrote on the Internet.

\subsection{Brand Value}

As a value for a particular brand, brand value has been defined as a consumer's perception of the benefits of a service or product relative to its cost, and it is defined as the overall customer evaluation of a particular service or product [34]. Sweeney and Soutar [35] provided four factors that influence consumers' attitudes and activities [36]: First, emotional value is the usefulness derived from consumers' feelings towards products, such as whether it makes them happy or not; secondly, social value is the ability of a product to strengthen a consumer's social self, such as making a good impression on others by buying the product; thirdly, price value refers to the usefulness associated with product costs, such as whether the price is reasonable; and fourthly, quality function value is defined as utility related to the product quality, such as whether the product shows consistent quality.

Zeithaml [34] states that brand value is an overall evaluation of the benefits relative to the cost of time, effort, and emotion that the consumer puts into a service or product, and the consumer's perception of the value of a brand or product can affect his or her behavior. Therefore, brand value has been used as a tool to derive effective marketing techniques based on research about consumption behavior. Although brand value is also influenced by various environmental factors surrounding consumers, including the social aspects they perceive [37], it is formed by a specific cause and attributed to a complex cause. Those characteristics may be the cause of the application of multidimensional concepts in describing values. 


\subsection{Research Hypotheses}

Boyd and Ellison [3] highlighted that SNS create a relationship network, and the information obtained through SNS is recognized as inspiring more confidence., more accuracy, and high reliability. Thus, more information is being exchanged through SNS. In the future, with the information through SNS becoming more accurate and reliable, it will expand into all fields, further promoting the use of SNS.

According to Smith [38], SNS advertising increases the interaction with consumers, which in turn bridges the gap between businesses and consumers. It also generates consumer interest through various information transmissions. Bickart and Schindler [28] and Anastasiei and Dospinescu [31] emphasized that consumers can be subdivided according into the type of SNS they use, so customized strategies can be established for each SNS type, enabling efficient brand marketing. Additionally, based on the theory of Smith [38], we believe that using SNS to market golf resorts is worthwhile.

Brown et al. [39] indicated that the relevance and quality of product information as well as the authenticity and reliability of the content provided online through SNS are essential. This information will affect buyers' behaviors; it can help improve consumer value and generate positive consumer attitudes, meaning information provided through SNS is of high value to consumers and brands $[40,41]$.

Moreover, consumers tend to trust and rely on word of mouth more than other information sources when making purchase decisions [15]. The opportunity for online word of mouth has increased greatly due to the proliferation of mobile devices and the internet, and consumers can access online information networks created by experienced users, despite the inability to reach them face to face. In addition, Bickart and Schindler [28,42] highlighted the importance of online word of mouth by noting that the impact of word of mouth is greater than general advertising or public relations, and the greater the impact of the word of mouth intention, the more a consumer's attitude is changed. It has also been confirmed that information obtained via word of mouth is logical and structured, which has a positive relationship with brand value because it creates empathy among consumers [43]. Indeed, there has been research conducted into how consumers' attitudes and values are changing owing to SNS advertising and online word of mouth. This body of literature includes research on the relationships between SNS advertising, online word of mouth, and emotional value [44,45]; between social value, SNS advertising, and online word of mouth $[3,46]$; between price value, SNS advertising, and online word of mouth [47,48]; between SNS advertising and online word of mouth [49]; and between quality functional value, SNS advertising, and online word of mouth. These studies found that the relations are close. Based on the theory, definition, and results of previous studies, the following hypotheses are set in this study.

Hypothesis 1 (H1). Golf resort SNS advertising and online word of mouth have an effect on emotional value.

Hypothesis 2 (H2). Golf resort SNS advertising and online word of mouth have an effect on social value.

Hypothesis 3 (H3). Golf resort SNS advertising and online word of mouth have an effect on price value.

Hypothesis 4 (H4). Golf resort SNS advertising and online word of mouth have an effect on quality function value.

All four hypotheses are shown in Figure 1. 


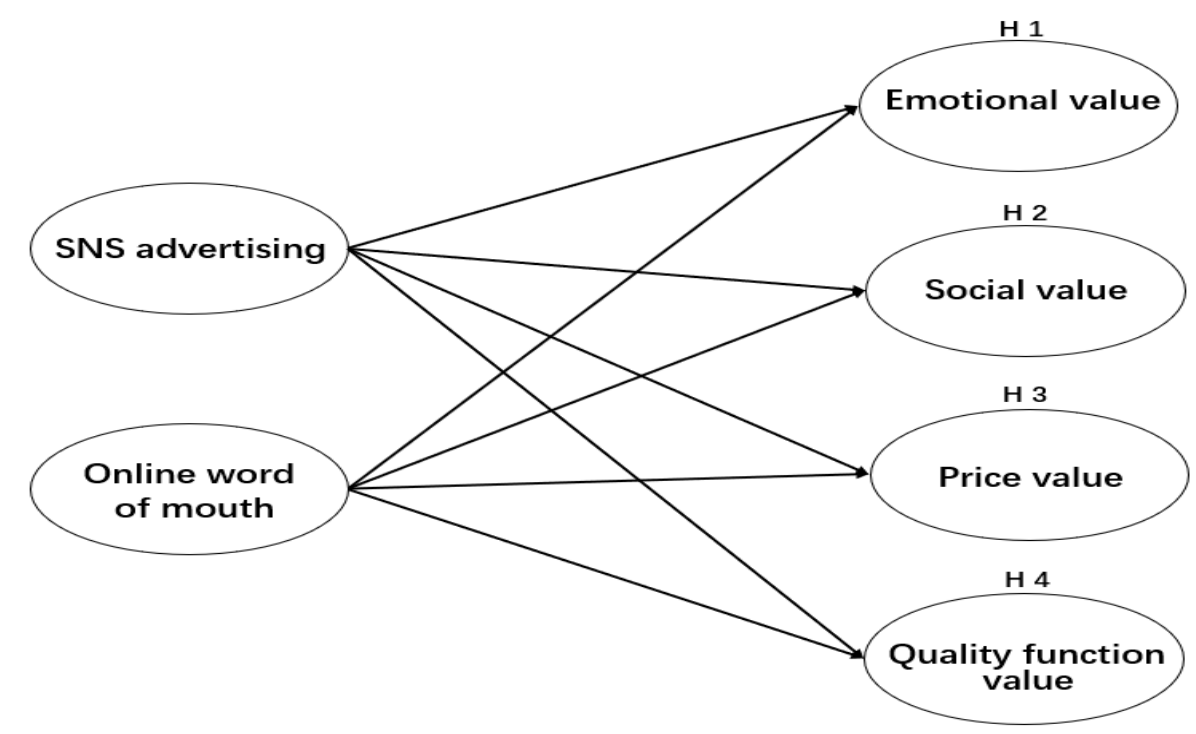

Figure 1. Proposed model of the structural relationships between social network services (SNS) advertising, online word of mouth, and brand value.

\section{Research Method}

\subsection{Questionnaire Design and Sampling}

The study's subjects comprised six membership golf courses located in Gyeongju City and Pohang City in Gyeongsangbuk-do, South Korea, where SNS advertising is used to attract consumers. The golf courses here are the subjects of the study as these resorts continuously provide SNS advertisements to consumers.

The golf resorts investigated in this study are representative cities of South Korea's cultural and marine tourism, and golf resorts are also recognized as differentiated resorts as they are connected to the tourism industry. It plays an important role in golf and tourism so it can be considered highly valuable for resort-related research. In addition, as these golf resorts have been showing SNS advertisements to consumers, they were deemed to be suitable for the study.

Particularly, these golf courses are equipped with facilities for accommodation, which are also used for various advertisements and online word of mouth. The questionnaire was conducted between May and July 2018. People who visited using SNS advertising and online word of mouth as a reference were selected as the object of investigation. The study included 271 respondents, and the questionnaires first confirmed what kind of SNS adverting and word of mouth led to the visit. The self-assessment registration method was used for the questionnaire, and all the questionnaires were written in the meeting room of the resort in consultation with the golf resort manager.

\subsection{Questionnaire}

A questionnaire was used as the survey tool in this study, and the details are as follows.

First, for the questions about golf resort advertising on SNS, questionnaires used in previous studies were modified and supplemented to meet the purpose of this study. The questions were based on the questionnaires used in the studies by Belch and Belch [50] and Boyd and Ellison [3], and they consisted of three items with five-point Likert scales.

Secondly, the questionnaire on golf resort online word of mouth was composed of six questions with five-point Likert scales. It was modified and supplemented to meet the purpose of this study, based on the studies by Gelb and Johnson [51] and Henning-Thurau et al. [15]. 
Third, the questionnaire items on the brand value of the golf resorts was based on the questionnaires used in Sweeny and Soutar [35], Keller [52], and Pappu et al. [53]. It was divided into five items on emotional value, five items on social value, five items on price value, and four items on quality functional value. Each question used a five-point Likert scale.

\subsection{Statistical Analysis}

The SPSS 20.0 program was used for frequency analysis, exploratory factor analysis, reliability analysis, and correlation analysis. Multiple regression analysis was used for the hypothesis test. The statistical significance level was set at $p<0.05$.

\section{Results}

\subsection{Demographic Characteristics}

The characteristics of the study subjects are shown in Table 1 . The study included 152 male (56.1\%) and 119 female $(43.9 \%)$ respondents. Most respondents were in their 40s, and they showed relatively high exposure to SNS advertisements. Seventy-one respondents $(26.2 \%)$ were in their $30 \mathrm{~s}$. This demographic may be due to the characteristics of golf. In this study, $48.7 \%$ were $40-49$ years old, $26.2 \%$ were $30-39$ years old, $19.9 \%$ were $50-59$ years old, and $5.2 \%$ were $20-29$ years old. In terms of marital status, 195 were married couples $(72 \%)$ and 76 were single (28\%). The education level is generally concentrated at college and above, confirming that the research subjects have a high educational level. The monthly income of 126 respondents (46.5\%) was between 3 million KRW and 4 million KRW. One hundred and eighty-two (67.2\%) participants responded that they have received and transmitted golf resort advertisements to others, indicating that the word of mouth is relatively high.

Table 1. Demographic characteristics of respondents.

\begin{tabular}{cccc}
\hline & Category & Frequency & Percent (\%) \\
\hline \multirow{2}{*}{ Gender } & Male & 152 & 56.1 \\
& Female & 119 & 43.9 \\
\hline \multirow{2}{*}{ Age } & 20-29th & 14 & 5.2 \\
& 30-39th & 71 & 26.2 \\
& 40-49th & 132 & 48.7 \\
& 50-59th & 54 & 19.9 \\
\hline \multirow{2}{*}{ Marital status } & Unmarried & 76 & 28.0 \\
& Married & 195 & 72.0 \\
\hline \multirow{2}{*}{ Education level } & Junior college & 129 & 47.6 \\
& Bachelor's degree & 133 & 49.1 \\
& Above Master's degree & 9 & 3.3 \\
\hline \multirow{2}{*}{ Monthly income } & Under 2 million (KRW) & 44 & 16.2 \\
& 2-3 million (KRW) & 91 & 33.6 \\
& 3-4 million (KRW) & 126 & 46.5 \\
& Above 4 million (KRW) & 10 & 3.7 \\
\hline Advertisement & Experienced & 182 & 67.2 \\
delivery status & Not Experienced & 89 & 32.8 \\
\hline & Total & 271 & 100.0 \\
\hline
\end{tabular}

\subsection{Exploratory Factor and Reliability Analyses}

Exploratory factor analysis was conducted to verify the validity of the survey data, and the results are as follows. First, the loading of all factors for advertising and word of mouth was above 0.5 , and the cumulative ratio was $66.331 \%$, indicating that the content of the questionnaire was measured reasonably. Furthermore, the results of the Kaiser-Meyer-Olkin (KMO) and Bartlett's spherical tests 
were $\mathrm{KMO}=0.839$ and Bartlett test value $=1384.691$ (degrees of freedom $=36$, and $p<0.001$ ), showing that the factor analysis is appropriate. The reliability of the factors was checked by using Cronbach's $\alpha$ test: the result for word of mouth was 0.745 , and for advertising was 0.882 , which confirmed the reliability. The results are shown in Table 2.

Table 2. Factor analysis of advertising and online word of mouth and Cronbach' $\alpha$.

\begin{tabular}{|c|c|c|c|}
\hline Content & Online Word of Mouth & Advertising & $h^{2}$ \\
\hline $\begin{array}{l}\text { You can often get information about the activity of this golf } \\
\text { resort through SNS advertisements. }\end{array}$ & 0.377 & 0.542 & 0.435 \\
\hline $\begin{array}{l}\text { You can often get information about the service of this golf } \\
\text { resort through SNS advertisements. }\end{array}$ & 0.223 & 0.913 & 0.884 \\
\hline $\begin{array}{l}\text { You can often get information about this golf resort service } \\
\text { through SNS advertisements with photo and video }\end{array}$ & 0.226 & 0.884 & 0.832 \\
\hline $\begin{array}{l}\text { I had obtained information about this golf resort through } \\
\text { comments, recommendations, and reviews on SNS. }\end{array}$ & 0.749 & 0.159 & 0.586 \\
\hline $\begin{array}{l}\text { I write comments, recommendations, and reviews about } \\
\text { this golf resort on SNS. }\end{array}$ & 0.782 & 0.268 & 0.683 \\
\hline $\begin{array}{l}\text { I get interested in comments, recommendations, and } \\
\text { reviews of this golf resort on SNS. }\end{array}$ & 0.676 & 0.332 & 0.568 \\
\hline $\begin{array}{l}\text { The comments, recommendations, and reviews of this golf } \\
\text { resort on SNS were vividly attached with photos and other. }\end{array}$ & 0.731 & 0.287 & 0.617 \\
\hline $\begin{array}{l}\text { The comments, recommendations, and reviews of this golf } \\
\text { resort can give you an indirect experience. }\end{array}$ & 0.768 & 0.277 & 0.666 \\
\hline $\begin{array}{l}\text { The comments, recommendations, and reviews of this } \\
\text { resort on SNS are realistically described. }\end{array}$ & 0.813 & 0.193 & 0.698 \\
\hline Total & 3.657 & 2.313 & \\
\hline (\%) Dispersion & 40.631 & 25.700 & \\
\hline (\%) Accumulation & 40.631 & 66.331 & \\
\hline Cronbach' $\alpha$ & 0.745 & 0.882 & \\
\hline
\end{tabular}

Note: $\mathrm{KMO}=0.839$ and Bartlett $=1384.691$, degrees of freedom $=36$, and $p<0.001$.

Secondly, the factor analysis result of brand value as a dependent variable was shown in four factors: the price, emotional, social, and quality function values. The load of all factors was higher than 0.5 , and the cumulative ratio was $73.706 \%$, which means the content of the questionnaire was measured reasonably. Furthermore, the KMO and Bartlett's spherical tests were $\mathrm{KMO}=0.918$ and Bartlett test value $=3808.454$ (degrees of freedom $=171$, and $p<0.001$ ), indicating that factor analysis is appropriate. In addition, the reliability of factor analysis was checked by using Cronbach's $\alpha$ test, and the results are as follows: price was 0.918 , emotion was 0.899 , social was 0.901 , and quality function was 0.872 , which also confirmed the reliability. The results are shown in Table 3.

\subsection{Correlation Analysis}

A correlation analysis was performed to determine the relationship between each factor, and the results are shown in Table 4. Although the correlations between factors were relatively high, Challagalla and Shervani [54] emphasized that correlations between factors should be significant in the correlation matrix, and at the same time, the correlation coefficient should not be 1 . However, if we reject the null hypothesis that the correlation coefficient is 1 , the factors are discriminant, and no multicollinearity problem occurs. 
Table 3. Factor analysis of brand value and Cronbach' $\alpha$.

\begin{tabular}{|c|c|c|c|c|c|}
\hline Content & Price & Emotional & Social & Quality & $h^{2}$ \\
\hline This golf resort brand gives me a good impression & 0.292 & 0.741 & 0.281 & 0.107 & 0.725 \\
\hline Using this golf resort brand gives me a lot of pleasure. & 0.226 & 0.812 & 0.145 & 0.186 & 0.766 \\
\hline I feel pleased with this golf resort brand. & 0.219 & 0.815 & 0.200 & 0.180 & 0.784 \\
\hline This golf resort brand makes me happy. & 0.138 & 0.740 & 0.207 & 0.231 & 0.663 \\
\hline I feel stable with this golf resort brand. & 0.145 & 0.713 & 0.287 & 0.232 & 0.666 \\
\hline Using this golf resort brand can raise social status & 0.283 & 0.326 & 0.663 & 0.191 & 0.662 \\
\hline Using this golf resort brand is something I admit. & 0.278 & 0.336 & 0.738 & 0.113 & 0.748 \\
\hline Using this golf resort brand can improve self-esteem. & 0.241 & 0.134 & 0.765 & 0.234 & 0.717 \\
\hline $\begin{array}{l}\text { Using this golf resort brand helps others to make a good } \\
\text { impression on me }\end{array}$ & 0.309 & 0.236 & 0.781 & 0.094 & 0.770 \\
\hline Using this golf resort brand makes me feel socially recognized. & 0.221 & 0.191 & 0.791 & 0.144 & 0.732 \\
\hline This golf resort brand offers a reasonable price. & 0.812 & 0.286 & 0.257 & 0.078 & 0.813 \\
\hline The usage cost of this golf resort brand is reasonable. & 0.816 & 0.240 & 0.297 & 0.063 & 0.816 \\
\hline This golf resort brand with high price/performance. & 0.820 & 0.204 & 0.246 & 0.141 & 0.794 \\
\hline This golf resort brand is economical. & 0.764 & 0.082 & 0.157 & 0.212 & 0.660 \\
\hline The price information of this golf resort brand is accurate. & 0.743 & 0.251 & 0.341 & 0.112 & 0.744 \\
\hline The quality of this golf resort brand is consistent. & 0.132 & 0.232 & 0.075 & 0.794 & 0.708 \\
\hline This golf resort brand is a well-made brand. & 0.063 & 0.174 & 0.122 & 0.870 & 0.806 \\
\hline The quality standard of this golf resort brand is acceptable. & 0.116 & 0.087 & 0.177 & 0.849 & 0.773 \\
\hline This golf resort brand with a high-level quality. & 0.190 & 0.288 & 0.219 & 0.701 & 0.658 \\
\hline Total & 3.787 & 3.684 & 3.527 & 3.006 & \\
\hline (\%) Dispersion & 19.932 & 19.389 & 18.565 & 15.821 & \\
\hline (\%) Accumulation & 19.932 & 39.321 & 57.886 & 73.706 & \\
\hline Cronbach' $\alpha$ & 0.918 & 0.899 & 0.901 & 0.872 & \\
\hline
\end{tabular}

Note: $\mathrm{KMO}=0.918$ and Bartlett $=3808.454$, degrees of freedom $=171$, and $p<0.001$.

Table 4. The correlation matrix of the measurement model.

\begin{tabular}{|c|c|c|c|c|c|c|}
\hline Variable & $\begin{array}{c}\text { SNS } \\
\text { Advertising }\end{array}$ & $\begin{array}{l}\text { Online Word } \\
\text { of Mouth }\end{array}$ & $\begin{array}{c}\text { Emotional } \\
\text { Value }\end{array}$ & $\begin{array}{l}\text { Social } \\
\text { Value }\end{array}$ & $\begin{array}{l}\text { Price } \\
\text { Value }\end{array}$ & $\begin{array}{c}\text { Quality } \\
\text { Function Value }\end{array}$ \\
\hline SNS Advertising & 1 & & & & & \\
\hline Online Word of Mouth & $0.601^{* * *}$ & 1 & & & & \\
\hline Emotional Value & $0.460^{* * *}$ & $0.487^{* * *}$ & 1 & & & \\
\hline Social Value & $0.404^{* * *}$ & $0.483^{* * *}$ & $0.607^{* * *}$ & 1 & & \\
\hline Price Value & $0.386^{* * *}$ & $0.490 * * *$ & $0.550 * * *$ & $0.645^{* * *}$ & 1 & \\
\hline Quality Function Value & $0.324^{* * *}$ & $0.271^{* * *}$ & $0.495^{* * *}$ & $0.439 * * *$ & $0.375^{* * *}$ & 1 \\
\hline
\end{tabular}

\subsection{Multiple Regression Analysis}

Table 5 shows the result of the multiple regression analysis conducted to investigate the influence relationship between golf resort SNS advertising and online word of mouth on the emotional, social, price, and quality function value components of brand value.

First, SNS advertising and online word of mouth have a positive effect on emotional value at the level of $p<0.001$. The verified results of the relative influence of SNS advertisement and online word of mouth on emotional value were $\beta=0.330$ and $\beta=0.262$, respectively, and the overall explanatory power was about $28.1 \%\left(\mathrm{R}^{2}=0.281\right)$. In the multi-regression analysis, a multicollinearity problem may arise among the independent variables. As shown in Table 5, based on standard values for tolerance (tolerance limit) and VIF (dispersion expansion factor), the tolerance is less than 1 and VIF is less than 10; when these numbers are close to 1 , there is low multicollinearity.

The Durbin-Watson value was analyzed to test the independence of the residuals, and it can be concluded that there is no autocorrelation when the value is close to 2 . The Durbin-Watson value is 1.885 , so we can adopt the hypothesis result of the multiple regression analysis. 
Table 5. Multiple regression analysis result of SNS advertising, online word of mouth, and emotional, social, price, and quality function values.

\begin{tabular}{|c|c|c|c|c|c|}
\hline \multicolumn{6}{|c|}{ SNS Advertising, Online Word of Mouth, and Emotional Value } \\
\hline Variable & $\mathbf{b}$ & $\beta$ & $\mathbf{t}$ & Tolerance & VIF \\
\hline (Constant) & 0.815 & & 2.920 & & \\
\hline SNS Advertising & 0.316 & 0.262 & $4.077^{* * *}$ & 0.639 & 1.565 \\
\hline Online Word of Mouth & 0.403 & 0.330 & $5.138^{* * *}$ & 0.639 & 1.565 \\
\hline \multicolumn{6}{|c|}{$\begin{array}{l}\mathrm{R}^{2}=0.281, \mathrm{~F}=53.380^{* * *}, \text { Durbin-Watson }=1.885 \\
* * * \\
p<0.001\end{array}$} \\
\hline \multicolumn{6}{|c|}{ SNS advertising, online word of mouth, and social value } \\
\hline (Constant) & 1.779 & & $7.609 * * *$ & & \\
\hline SNS Advertising & 0.177 & 0.178 & $2.721^{* *}$ & 0.639 & 1.565 \\
\hline Online Word of Mouth & 0.377 & 0.376 & $5.745^{* * *}$ & 0.639 & 1.565 \\
\hline \multicolumn{6}{|c|}{$\begin{array}{l}\mathrm{R}^{2}=0.253, \mathrm{~F}=46.328^{* * *}, \text { Durbin-Watson }=2.096 \\
* * p<0.01, * * *<0.001\end{array}$} \\
\hline \multicolumn{6}{|c|}{ SNS advertising, online word of mouth, and price value } \\
\hline (Constant) & 1.120 & & $3.916^{* * *}$ & & \\
\hline SNS Advertising & 0.174 & 0.143 & $2.192 *$ & 0.639 & 1.565 \\
\hline Online Word of Mouth & 0.496 & 0.404 & $6.174 * * *$ & 0.639 & 1.565 \\
\hline \multicolumn{6}{|c|}{$\begin{array}{l}\mathrm{R}^{2}=0.253, \mathrm{~F}=46.328^{* * *}, \text { Durbin-Watson }=1.863 \\
{ }^{*} p<0.05, * * *<<0.001\end{array}$} \\
\hline \multicolumn{6}{|c|}{ SNS advertising, online word of mouth, and quality function value } \\
\hline (Constant) & 1.654 & & $5.233 * * *$ & & \\
\hline SNS Advertising & 0.309 & 0.251 & $3.525^{* * *}$ & 0.639 & 1.565 \\
\hline Online Word of Mouth & 0.150 & 0.120 & 1.688 & 0.639 & 1.565 \\
\hline $\begin{array}{l}\mathrm{R}^{2}=0.114, \mathrm{~F}=17.553 * * \\
* * * p<0.001\end{array}$ & Watson & & & & \\
\hline
\end{tabular}

The hypothesis tests are as shown in Table 5 and Figure 2. First, SNS advertising has a positive effect on social value at the $p<0.01$ level, and online word of mouth has a positive effect at the $p<0.001$ level. In addition, the values for tolerance, VIF, and Durbin-Watson fit the criteria.

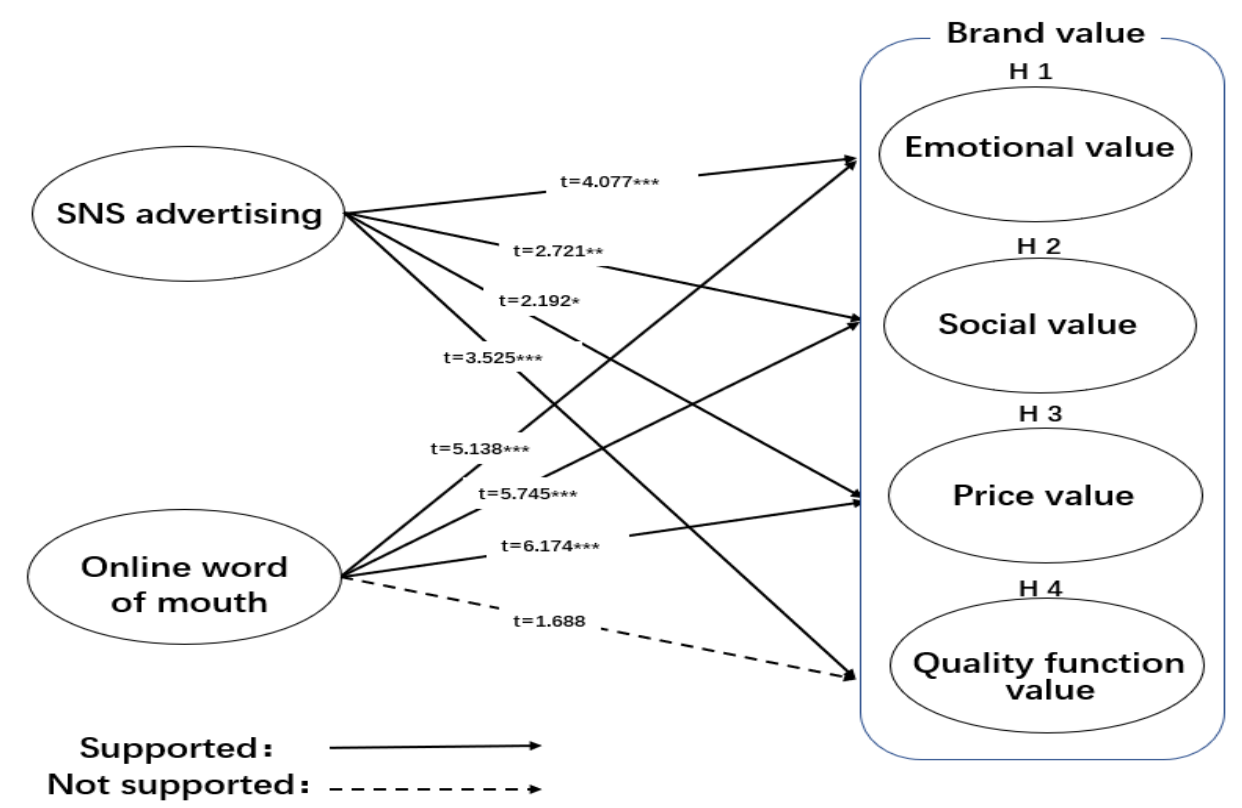

Figure 2. Results of the structural equation model. 
Secondly, SNS advertising has a positive effect on price value at the $p<0.05$ level, and online word of mouth has a positive effect at the $p<0.001$ level. Moreover, the values for tolerance, VIF, and Durbin-Watson fit the criteria.

Thirdly, SNS advertising has a positive effect on the value of quality function at the $p<0.001$ level, and the values for tolerance, VIF, and Durbin-Watson fit the criteria.

\section{Conclusions and Discussion}

\subsection{Conclusions}

First, SNS advertising and online word of mouth were shown to have a positive effect on the emotional value of consumers. The results showed that SNS advertising provides golf resort consumers with satisfaction owing to brand information, which is important in inducing consumer purchasing behavior [14]. Grewal et al. [55] also said that a strategy is necessary to increase the brand interest of consumers. Dodds et al. [45] highlighted that advertising quality is an important factor affecting consumers' emotional value. Therefore, golf resorts must utilize online advertising and word of mouth to continuously increase the emotional value of consumers.

Secondly, SNS advertising and online word of mouth positively affected social values. Boyd and Ellison [3] stated that social values play an important role as they form a network through the content created for online adverting and word of mouth. Laroche et al. [46] also highlighted that when a network between consumers and service providers is formed, consumers will continue to participate and the level of social value will increase. Golf resorts must therefore provide advertisements and word of mouth to enhance the social value of consumers.

Thirdly, SNS advertising and online word of mouth had a positive effect on price value according to Aaker [47] and Simon and Sullivan [48]. Since SNS changes traditional brand values and creates new values through SNS, golf resorts must continuously manage SNS adverting and word of mouth to increase consumer price value.

Fourthly, SNS advertising had a positive effect on quality function value. Online word of mouth was not statistically significant for quality function value. For this, Vigneron and Johnson [49] stated that the value of the quality function is positive when it is judged that the quality of the brand perceived by the consumer is relatively superior to that of the same company [56]. Wiedmann et al. [56] suggested that word of mouth must be prioritized as it can become negative, while the word of mouth information provided is lower than that of the online word of mouth for the same company.

To summarize our results, SNS advertising and word of mouth services can increase the brand value perceived by consumers and lead to repeat customers. These efforts will lead consumers to continue to help increase the value of the brand.

\subsection{Discussion}

\subsubsection{Implications and Contributions}

The theoretical and practical implications are as follows. First, our study builds on the efforts of its predecessors by providing a more thorough verification of the relationship between SNS advertising, word of mouth, and brand value for golf resorts and including a framework for follow-up studies. Additionally, unlike previous studies, online word of mouth did not affect the quality function value, whereas SNS advertising showed a significant effect on the quality function value. These results generally dismiss the hypothesis that SNS advertising and online word of mouth have a significant effect on brand value. This is the result of the number of SNS advertisements in the golf resort industry or the quality level of the information.

As a practical implication, first, it is necessary to increase brand value by actively using SNS advertisements and online word of mouth with consumers according to technological changes. Rather than unilateral advertising through the media, SNS advertisements with channels to communicate 
with consumers should improve corporate performance. Secondly, the analysis results show that online word of mouth has greater influence on brand value than SNS advertising, and, in the future, companies will implement online SNS advertising techniques to maximize consumer satisfaction. Thirdly, we found that SNS advertisements had a significant effect on quality function value, but online word of mouth was not significant. This can be because consumers are not aware of the quality function value due to the lack of recognition when an SNS advertisement is more actively conducted in a golf resort, which is a similar company, as suggested in the conclusion. Therefore, SNS advertising should be conducted more aggressively than other forms of advertising to attract more consumers.

\subsubsection{Limitations and Future Research Directions}

First, this study only verified the relationship between SNS advertisements, word of mouth, and the brand value of golf resorts. However, conducting research by adding various factors in future studies is necessary. For example, expanding the scope of research by verifying brand value, satisfaction, and loyalty through SNS advertisements and word of mouth of golf resorts is vital. Secondly, this research was conducted without controlling the number of SNS advertisements; however, the results may vary depending on the number of SNS advertisements. Therefore, it is necessary to conduct research by controlling the number of SNS advertisements. Thirdly, this study is difficult to generalize, as it is a cross-sectional study at a certain timepoint. Therefore, in future studies, conducting longitudinal studies is necessary to generalize the research results. Fourthly, this study is limited to the area of the study; thus, future studies should compare research results among golf resorts across the country or even from other countries.

Author Contributions: Data curation, T.C. (Taesoo Cho); formal analysis, T.C. (Taeyoung Cho); methodology and project administration, H.Z.; software, T.C. (Taeyoung Cho); writing-original draft, T.C. (Taesoo Cho), T.C. (Taeyoung Cho); writing-review and editing, H.Z., G.Z. All authors have read and agreed to the published version of the manuscript.

Funding: This research was supported by the Strategic Priority Research Program of Chinese Academy of Sciences (No. XDA23000000).

Acknowledgments: We are grateful to all our interview partners for spending their time and efforts on answering our questions. We thank three external reviewers who helped to significantly improve this paper.

Conflicts of Interest: The authors declare no conflict of interest.

\section{References}

1. Hsu, L.; Lee, S.N. Learning tourism English on mobile phones: How does it work? J. Hosp. Leis. Sport Tour. Educ. 2011, 10, 85-94. [CrossRef]

2. Wu, J.; Fan, S.; Leon Zhao, J. Community engagement and online word of mouth: An empirical investigation. Inf. Manag. 2018, 55, 258-270. [CrossRef]

3. Boyd, D.M.; Ellison, N.B. Social network site: Definition, history, and scholarship. J. Comput. Mediat. Commun. 2008, 13, 210-223. [CrossRef]

4. Li, Y.; Gao, X.; Du, M.; He, R.; Yang, S.; Xiong, J. What Causes Different Sentiment Classification on Social Network Services? Evidence from Weibo with Genetically Modified Food in China. Sustainability 2020, 12, 1345. [CrossRef]

5. Kaplan, A.M.; Haenlein, M. The britney spears universe: Social media and viral marketing at its best. Bus. Horiz. 2012, 55, 27-31. [CrossRef]

6. ComScore. ComScore Reports Global Search Market Growth of 46 Percent in 2009.2009. Available online: https://www.comscore.com/Insights/Press-Releases/2010/1/Global-Search-Market-Grows-46-Percentin-2009 (accessed on 25 May 2020).

7. Thackeray, R.; Neiger, B.L.; Hanson, C.L.; McKenzie, J.F. Enhancing promotional strategies within social marketing programs: Use of Web 2.0 social media. Health Promot. Pract. 2008, 9, 338-343. [CrossRef]

8. Dellarocas, C. The digitization of word of mouth: Promise and challenges of online feedback mechanism. Manag. Sci. 2003, 49, 1407-1424. [CrossRef] 
9. Sun, T.; Youn, S.M.; Wu, G.H.; Kuntaraporn, M. Online word-of-mouth (or mouse): An exploration of its antecedents and consequences. J. Comput. Mediat. Commun. 2006, 11, 1104-1127. [CrossRef]

10. Feng, J.; Liu, B. Dynamic Impact of Online Word-of-Mouth and Advertising on Supply Chain Performance. Int. J. Environ. Res. Public Health 2018, 15, 69. [CrossRef]

11. Petrick, J.F.; Backman, S.J. An examination of the determinants of golf travellers' satisfaction. J. Travel Res. 2002, 40, 252-258. [CrossRef]

12. Baek, W.Y.; Kim, K.A.; Kim, D.H.; Byon, K.K. The Impacts of the Perceived Golf Course Brand Globalness on Customer Loyalty through Multidimensional Perceived Values. Sustainability. 2020, 12, 978. [CrossRef]

13. López-Bonilla, J.M.; Reyes-Rodríguez, M.C.; López-Bonilla, L.M. Interactions and Relationships between Personal Factors in Pro-Environmental Golf Tourist Behaviour: A Gender Analysis. Sustainability 2020, 12, 332. [CrossRef]

14. Ducoffe, R.H. Advertising value and advertising on the web. J. Advert. Res. 1996, 36, 21-35.

15. Henning-Thurau, T.; KGwinner, G.W.; Gremler, D. Electronic word-of-mouth via consumer-opinion platforms: What motives consumers to articulate themselves on the internet? J. Interact. Mark. 2004, 18, 38-52. [CrossRef]

16. Van Doorn, J.; Lemon, K.N.; Mittal, V.; Nass, S.; Pick, D.; Pirner, P.; Verhoef, P.C. Customer engagement behavior: Theoretical foundations and research directions. J. Serv. Res. 2010, 13, 253-266. [CrossRef]

17. Safko, L.; Brake, D.K. The Social Media Bible: Tactics, Tools and Strategies for Business Success; John Wiley \& Sons Ltd.: Hoboken, NJ, USA, 2009.

18. Armano, D. Six Social Media Trends for 2010. 2009. Available online: https://hbr.org/2009/11/six-socialmedia-trends (accessed on 25 May 2020).

19. Seiler, S.; Yao, S.; Wang, W. Does online word of mouth increase demand? (And How?) Evidence from a natural experiment. Mark. Sci. 2017, 36, 1-58. [CrossRef]

20. Hassan, M.U.; Fatima, S.; Akram, A.; Abbas, J.; Hasnain, A. Determinants of Consumer Attitude Towards Social-Networking Sites Advertisement: Testing the Mediating Role of Advertising Value. Middle-East J. Sci. Res. 2013, 16, 319-330.

21. Park, Y.S.; Lee, K.; Lee, J. The types of social capital formed on social networking services (SNS) and their effects on consumer preference for a product type. Korean Acad. Soc. Bus. Adm. 2012, 41, 1619-1641.

22. Chang, K.T.; Chen, W.; Tan, B.C. Advertising effectiveness in social networking sites: Social ties, expertise, and product type. Eng. Manag. 2012, 59, 1-10. [CrossRef]

23. Taylor, D.G.; Lewin, J.E.; Strutton, D. Friends, fans, and followers: Do ads work on social networks? How gender and age shape receptivity. J. Advert. Res. 2011, 51, 258-275. [CrossRef]

24. Mun, S.-H.; Cho, T.-S. A study on the influence of golf course SNS information on choice satisfaction and re-use. Korea J. Sports Sci. 2016, 25, 855-868.

25. Balasubramanian, S.; Mahajan, V. The economic leverage of the virtual community. Int. J. Electron. Commer. 2001, 5, 103-138.

26. Anastasiei, B.; Dospinescu, N. Electronic word-of-mouth for online retailers: Predictors of volume and valence. Sustainability 2019, 11, 814. [CrossRef]

27. Wilson, A.E.; Giebelhausen, M.D.; Brady, M.K. Negative word of mouth can be a positive for consumers connected to the brand. J. Acad. Mark. Sci. 2017, 45, 534-547. [CrossRef]

28. Bickart, B.; Schindler, R.M. Expanding the scope of word of mouth: Consumer-to-consumer information on the internet. Adv. Consum. Res. 2002, 29, 428-430.

29. Jahn, B.; d Kunz, W. How to transform consumers into fans of your brand. J. Serv. Manag. 2012, $23,344-361$. [CrossRef]

30. Azar, S.L.; Machado, J.C.; Vacas-de-Carvalho, L.; Mendes, A. Motivations to interact with brands on Facebook towards a typology of consumer brand interactions. J. Brand Manag. 2016, 23, 153-178. [CrossRef]

31. Anastasiei, B.; Dospinescu, N. A model of the relationships between the Big Five personality traits and the motivations to deliver word-of-mouth online. Psihologija 2018, 51, 215-227. [CrossRef]

32. Wilker, L. Travel Industry Prospects Bright Despite Economic Uncertainty: Many Expect to Travel at Least as Much for Holidays and in Coming Year; Deloitte Development: New York, NY, USA, 2007.

33. Krame, G.; Gastpar, M.; Gupta, P. Cooperative strategies and capacity theorems for relay networks. IEEE Trans. Inf. Theory. 2005, 51, 3037-3063. [CrossRef]

34. Zeithaml, V.A. Consumer perceptions of price and value: A means-end model and synthesis of evidence. J. Mark. 1988, 52, 2-22. [CrossRef] 
35. Sweeney, J.C.; Soutar, G.N. Consumer perceived value: The development of a multiple item scale. J. Retail. 2001, 77, 203-220. [CrossRef]

36. Zhang, J.; Wang, J.; Min, S.D.; Chen, K.K.; Huang, H. Influence of curriculum quality and educational service quality on student experiences: A case study in sport management programs. J. Hosp. Leis. Sport Tour. Educ. 2016, 18, 81-91. [CrossRef]

37. Kahle, L.R. Social Value and Social Change: Adaptation to Life in America; Praeger: New York, NY, USA, 1983.

38. Smith, G. Tagging: People-Powered Metadata for the Social Web; New Riders Publishing: Berkeley, CA, USA, 2008.

39. Brown, J.; Broderick, A.J.; Lee, N. Word of mouth communication within online communities: Conceptualizing the online social network. J. Interact. Mark. 2007, 21, 2-20. [CrossRef]

40. Murray, K.B. A test of services marketing theory: Consumer information acquisition activities. J. Mark. 1991, 55, 10-25. [CrossRef]

41. Eelen, J.; Özturan, P.; Verlegh, P. The differential impact of brand loyalty on traditional and online word of mouth: The moderating roles of self-brand connection and the desire to help the brand. Int. J. Res. Mark. 2017, 34, 872-891. [CrossRef]

42. López-Bonilla, J.M.; Reyes-Rodríguez, M.D.C.; López-Bonilla, L.M. The Environmental Attitudes and Behaviours of European Golf Tourists. Sustainability 2018, 10, 2214. [CrossRef]

43. Lipsman, A.; Mudd, G.; Rich, M.; Bruich, S. The power of "Like": How brands reach (and influence) fans through social-media marketing. J. Advert. Res. 2012, 52, 40-52. [CrossRef]

44. Rotzoll, K.; Haefner, J.E.; Sandage, C.J. Advertising and classical liberal world view. In Advertising in Society: Classic and Contemporary Readings on Advertising's Role in Society; Hovland, R., Wilcox, G.B., Eds.; NTC Business Books: Lincolnwood, IL, USA, 1989; pp. 27-41.

45. Dodds, W.B.; Monroe, K.B.; Dhruv, G. Effects of price, brand, and store information on buyers' product evaluations. J. Mark. Res. 1991, 28, 307-319.

46. Laroche, M.; Habibi, M.R.; Richard, M.O. To be or not to be in Social Media: How brand loyalty is affected by social media? Int. J. Inf. Manag. 2013, 33, 76-82. [CrossRef]

47. Aaker, D.A. Building Strong Brands; The Free Press: New York, NY, USA, 1996.

48. Simon, C.J.; Sulivan, W.S. The measurement and determinants of brand equity: A financial approach. Mark. Sci. 1993, 12, 28-52. [CrossRef]

49. Vigneron, F.; Johnson, L.W. Measuring perceptions of brand luxury. Brand Manag. 2004, 11, 484-506. [CrossRef]

50. Belch, G.E.; Belch, M.A. Introduction to Advertising and Promotion; McGraw-Hill Education-Europe: London, UK, 1995.

51. Gelb, B.; Johnson, M. Word of mouth communication: Causes and consequences. J. Health Care Mark. 1995, $15,54-58$.

52. Keller, K.L. Conceptualizing measuring and managing customer: Based brand equit. J. Mark. 1993, 57, 1-22. [CrossRef]

53. Pappu, R.; Quester, P.G.; Cooksey, R.W. Consumer-based brand equity; Improving the measurement empirical. J. Prod. Brand Manag. 2005, 15, 4-14. [CrossRef]

54. Challagalla, G.N.; Shervani, T.A. Dimension and types of supervisory control: Effects on salesperson performance and satisfaction. J. Mark. 1996, 60, 89-105. [CrossRef]

55. Grewal, D.; Monroe, D.K.; Krishnan, R. The effects of price-comparison advertising on buyers' perceptions of acquisition value, transaction value, and behavioral intentions. J. Mark. 1998, 62, 46-59.

56. Wiedmann, K.; Hennings, N.; Siedles, A. Value-based segmentation of luxury consumption behavior. Psychol. Mark. 2009, 26, 625-651. [CrossRef]

(C) 2020 by the authors. Licensee MDPI, Basel, Switzerland. This article is an open access article distributed under the terms and conditions of the Creative Commons Attribution (CC BY) license (http://creativecommons.org/licenses/by/4.0/). 